\title{
FAMILY COPING STRATEGIES IN THE MIDST OF CORONA CRISIS
}

\author{
Devi Yulianti*, ORCID ID: 0000-0003-0885-4687, \\ Intan Fitri Meutia, ORCID ID: 0000-0001-9818-8459 \\ Universitas Lampung, JL. Prof. Dr. Soemantri Brojonegoro No.1 Rajabasa, BandarLampung, Indonesia \\ *Corresponding author: Devi Yulianti, devi.yulianti@fisip.unila.ac.id
}

Received: 10. 11. 2021

Accepted: 11. 19. 2021

\begin{abstract}
The family as the unit in the social system has an important role and becomes the first social environment to introduce love, affection, social culture, and religion. When the world is suffering from the COVID-19 pandemic, the families are also affected by some impacts included: family health problems; family economic; family harmonization; family socio-psychology; and socio-culture. The family health is composed of fundamental dimensions: family social climate; family integrity; family functioning; family resistance and family coping. The family coping concept is the capacity of the family to confront, mobilize, and act on stressful events. This article illustrates the aspects of family health and coping strategies in the midst of the COVID-19 in Indonesia. It aims to inform and be the reference for further study related to the family adaptation in the corona crisis. We reviewed many works of literature in the form of articles from various journals. During the COVID-19 pandemic, families must be able to survive. COVID-19 pandemic does not only affect physical but also mental health. The way to deal with the events depend on family characteristics, the severity of the events and family support. There are two types of coping strategies that families in Indonesia usually adopt including reducing expense and increasing income.
\end{abstract}

Keywords: coping strategies, corona crisis, COVID-19, family health, family coping.

Rezumat. Familia, ca unitate în sistemul social, are un rol important în a deveni primul mediu social care introduce dragostea, afecțiunea, cultura socială și religia. Când lumea suferă de pandemia de COVID-19, familiile sunt afectate și de unele impacturi, printre care: probleme de sănătate a familiei; economie familială; armonizarea familiei; socio-psihologia familiei și socio-cultura. Sănătatea familiei este compusă din dimensiuni fundamentale: climatul social familial; integritatea familiei; funcționarea familiei; rezistența și adaptarea familiei. Conceptul de coping familial este capacitatea familiei de a se confrunta, de a se mobiliza și de a acționa asupra evenimentelor stresante. Acest articol ilustrează aspectele legate de sănătatea familiei și strategiile de coping în pandemia COVID-19 în Indonezia. Acesta își propune să informeze și să fie referintă pentru studii ulterioare legate de adaptarea familiei în criza corona. Am trecut în revistă multe lucrări de literatură sub formă de articole din diverse reviste. În timpul pandemiei de COVID-19, familiile trebuie să poată supraviețui. Pandemia de COVID-19 nu afectează doar sănătatea fizică, ci și psihică. Modul de a face față evenimentelor depinde de caracteristicile familiei, de severitatea evenimentelor și de 
sprijinul familiei. Există două tipuri de strategii de coping pe care familiile din Indonezia le adoptă de obicei, inclusiv reducerea cheltuielilor și creșterea veniturilor.

Cuvinte cheie: strategii de coping, criză corona, COVID-19, sănătatea familiei, coping familial.

\section{Introduction}

The family as the unit in the social system has an important role and becomes the first social environment to introduce love, affection, social culture, religion, and morals. It is also the main defense for negative influence from the social dynamic. Religion is an important aspect of life for Indonesian and is the principle of state ideology. Religion is not only the expression of the individual relationship' with god but also the greatest influence on family norms and social control. Therefore, the parents introduce religion to the children at a young age and expect the religion to guide their life. When the COVID-19 pandemic hit the world, the families were also affected by some impacts included: family health problems; family economic; family harmonization; family socio-psychology; and socio-culture. Indonesian society cannot be separated from religion and culture, so that the expressions of a religion are embedded in the culture. The culture in Indonesia is an identity of the ethnic groups and perceiving culture can improve the position of the ethnic group among multiethnic in Indonesia. The family system introduces individual to value, customs and cultures that are practiced within the society. Through those experiences, adults gain the understanding, emotional, and moral commitment to act among the communities.

Indonesian society considers that having children is a blessing and contributes to family well-being and improves the quality of married life. While the definition of health is diverse in Indonesia. It is strongly affiliated with the religious and cultural backgrounds of Indonesian [1 - 2]. For most Indonesian, health is a condition needed to accomplish daily activities, in other words, health is function. Someone is categorized as healthy if he/she can do things. The way of Indonesian defines health is associated with their poor performance in preventing disease. Because they will not take any actions related to their health condition if their daily activities have not been hampered. It is predominantly caused them to delay seeking care. The majority of Indonesian, only seek medical help when their illness reaches advanced stages resulting in prolonged treatment, more costly treatment, or even ineffective treatment [3]. Moreover, according to the Indonesian belief that health is granted by God, it is a test from God because an individual has failed to follow the prescribed religious principles [2]. Besides that, health and illness are also associated with balanced harmony.

Families ought to be able to survive in the midst of a corona crisis. COVID-19 pandemic does not only affect physical but mental health. Social distancing, self-quarantine, school, and work from home have become a new normal these days [4]. The uncertain condition makes the family the target of social and economic aspects needs cooperation among the members. The balance between work and family life is difficult to maintain in modern society because of the demands of work and the role in a family environment. This could lead to stressful situations for an individual. Work-family conflict is a psychological aspect. The pressure of sharing the role of work in the household produces negative consequences. The level of participation in the households will create difficulties to participate in work that resulted in home conflict. In the midst of the COVID-19 crisis, many employers have been recommended to work from home. Some are happy about this situation because of the support from multimedia technology to effectively communicate with others. This is based on the research that there were still $36 \%$ of Indonesian who were not able to adapt to 
technology although it could foster collaboration with co-workers during work from home since they have difficulties to separate work and home life. But some will find it difficult to do everything at the same time at home. The importance of stay at home policy is challenging during COVID-19 outbreaks. Stay at home policy becomes more complex. The family tends to respond to the corona crisis differently. From Wahyuni' research [5], it was known that social media impacted personal mental health. This might trigger stress. Furthermore, people tend to be panic, worried, and restless. Because many people around the world are suffering from mental illness in the midst of the corona crisis, World Health Organization creates procedures to support people with a mental health condition from the impact of the pandemic crisis.

The policy is challenged for implementation in society because of many interests, motivations, and willingness [6]. Participatory provides space for various parties involving in formulation, implementation also monitoring government activities. Thus this active role of community is important to carry out development programs. Participatory concepts involve lots of parties that provide motivation, knowledge, experience, skills, and access to partnerships especially in social and economic fields [7 - 9]. Among many development programs in Indonesia, The Family Empowerment Post (Posdaya) has three pillars that can accommodate community needs in the economy, health, and social sectors. Posdaya is important to deliver information, education, as a communication forum and coordinating activities to strengthen family function in the field of economy, environment, health, and social [10 - 11]. Posdaya is a group of people in the community who' aware and enthusiastic in carrying the duty in providing services in the field of health and education for children and pregnant women and in the field of economic sectors.

Family function and empowerment are really important to achieve individual and social welfare in the economy, health, and social fields [12]. The symptoms of fear, anxiety, and uncertainty among the different populations across countries may associate with distress in the health system [13]. This imposes the necessity for monitoring public health in the different categories of society. There are two types of family-children balance well-being environment: physical and behavioral. The physical environment requires related elements to children' ability to physically connect with their environment such as; home layout, the bedroom comfort, playground, study area, air quality, temperature, lights, and noise effect [14]. Physical environments impact children' participations in positively or negatively physical activities. While the behavior environment relates to the way the children connect with others and may lead to interaction or distraction. In health sector, Posdaya serves pregnant women, toddler and elderly at Posyandu, provides empowerment for Posyandu officers, activists, and cadres to increase motivation, knowledge, skills in maintaining the health management system for the family and environment. In the education sector, Posdaya improves knowledge and skills on learning media for teachers in early childhood education and kindergarten. In the economic sector, Posdaya creates and develops small business groups to increase family income and welfare. While the problems aroused during the implementation of the Posdaya Program in rural areas were: low levels of organizational communications among administrators, lack of community involvement, low participation, motivation, community apathy, lack of rural government initiative, and support to use their budget.

The Family Empowerment Post has been implementing for community development in rural areas, especially in education, economy, and health. Even though it only provided minimum standards of service in terms of transferring knowledge and skills to the community. The responsiveness, productiveness, and innovation are needed to increase the motivation, 
knowledge, and entrepreneurial skills of rural communities to maintain the health and welfare of families in the midst of COVID-19 in Indonesia. The theory stated that the ability to cope was not an inborn personality. It is related to physical and supported by the environment. We ought to adapt in some new ways to survive in the environment. The theory of coping emphasized the process to deal with the problems, implement the skill to respond to problematic situations, and apply for self-management in the midst of difficult situations. This article illustrates the aspects of family health and coping strategies in the COVID-19 crisis in Indonesia with the aim to analyze family health and coping strategies. While the contributions of this research are giving additional information on family health aspects particularly in dealing with the pandemic crisis and the source of references for related parties to conduct the research and policy problems. We have reviewed some works of literature to guide us to answer the problem in this article. They are Indonesian family characteristics related to health aspects management and family coping.

\section{Indonesian Family Characteristics}

Indonesia as a multicultural country consists of hundreds of ethnic groups. Marriage remains common and universal in various ethnic groups [15]. However it remains universal, the number of non-married people is increasing particularly in big cities. One reason for this trend is many young people prefer to pursue careers and studies rather than marriage. In many ethnic groups, it is common for adults to stay with their parents after marriage for a period of time until the new couples are able to afford to form their own independent households. Intergenerational living arrangements remain common in Indonesian society even though they are declining nowadays. It is because there are more work and life opportunities available in the city that promotes urbanization [16]. In a social context, the cohabitation living arrangements differentiate a collective culture such as Indonesian from an individualistic society. Adults involved in cohabitation living arrangements are considered to be adhering to the tradition to fulfilling their lifelong obligations to their parents, in the form of support and respect nurtured by filial piety. These are some considerations of adults living with their parents after marriage: 1 ). the inheritance of land and property; 2 ). the norms in Indonesian society for child care; and 3). the decisions of the timing for childbearing. Land and property inheritance will consider the adat law (local ethnic-based laws and customs); each ethnicity has its own arrangements. While for child care the grandparents will usually look after the grandchildren. The duty is seen as the investment for the future with the expectation that they will be taken care of by the children and the grandchildren in the future [17].

Cohabitation refers to the process of sharing the experience and living within the common and defines time and space. It is a process that allows individuals, communities, and organizations in managing meaningful and stable relationships. Living together can be described by three levels of relationship: emotional, organizational, and social. The cohabitation relationship on an emotional level addresses the issue of family relationships between parents and children; couples relationships living together with peer groups, and the complexity in managing the new lifestyle. An organizational context is a place where many individuals spend a large part of their lives, building relationships, setting up ways of being together, investing energy, emotion, and hopes. While the social level relationship of cohabitation refers to the context of civil society, the interaction in the community in a broader sense on the global social context [18]. 


\section{Family Coping}

Collective coping is the behavior and thought of some individuals to overcome the stressors internally or externally. These activities are affected and influenced by any media to form people' mindsets to face problematic situations [19]. In relation to family coping, this means the capability of the family to act and respond to the appearances of stressors that involve behavior and cognitive actions to overcome the pressures. Meanwhile, the strategies of coping are expressed through the communication and support to the positive feeling among family members. These strategies might be changed related to the environments as the results of conflicts, demands, disturbance among family and community. From the explanation we conclude that the ability to cope will be changed and modified based on particular conditions to form well-functioned communication, self-esteem, family organization, family bonds, and family unity within the family system.

\section{Corona Crisis}

A Crisis is a situation as the result of unexpected and unpredictable events. A crisis requires rapid decisions making to limit the various effects. The damage caused by the crisis may vary based on the nature of the crisis. The crisis could affect health safety badly. Then it needs crisis management as the implementation of the strategies to overcome sudden negative events and potential risks. There are many stages for forming effective crisis management ranging from pre-crisis diagnosis, crisis response, and post-crisis. COVID-19 has influenced every aspect of normal life. This pandemic is impacted daily life, economic sectors, education, health, political security, work-life and social networks. From many works of literature, we have noted that governments around the world responded and acted differently to face this pandemic and resulted in particular success in dealing with this pandemic [20]. Coronavirus disease 19 has turned into an unexpected crisis around the globe within countries and societies. This crisis must be faced and we must adapt to new ways of dealing with the nature impact [21].

The coronavirus disease 19 has become a health crisis that resulted in many crises vulnerably. There must be a rapid policy response for the consequence of this crisis. There are needs for contributions, power, and participation from many parties to support the research and better policy. Many countries have shown the strategies to respond to the corona crisis as shown in the quadrants of effective control in the midst of the COVID-19 pandemic from Baniamin, Rahman, and Hasan' research [22]. According to their research, there were specific scenarios to control such pandemic illustrated in four quadrants. Q1 shows effective mitigating with good preventive strategies. Hong Kong, Japan, and South Korea were examples of the countries that have prevented small-scale coronavirus outbreaks. Q2 means the rapid mitigating strategy but does not have good preventive ways. China was the example of a country that failed to protect its citizens during the coronavirus outbreaks. Q3 shows the ineffective ways of mitigating and effective preventive actions. The Q4 shows the ineffective mitigating strategy with effective preventive ways. Below is the figure of those four quadrants.

\section{Method}

This article uses documents as the research method. We reviewed many works of literature in the form of articles in various journals from the year 2011 to 2021. A literature review is used for looking at the theories which support our research. We review the works of literature on, Indonesian Family Characteristics and Family Coping Strategies. 


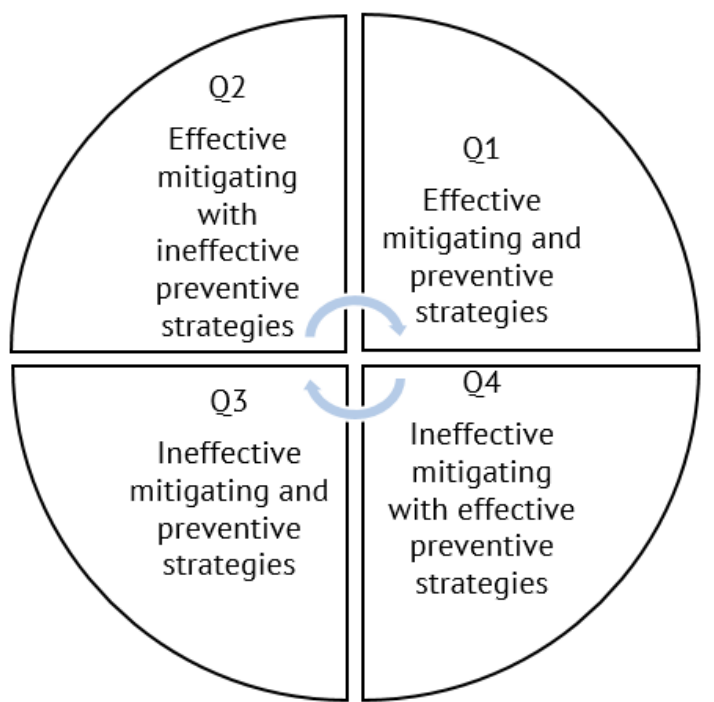

Figure 1. Scenarios to control a pandemic. Source: Baniamin et al (2020).

The literature review helps to maintain a framework in accordance with the theory, findings, and results to answer the research question. The purpose of the literature review is to be a theoretical basis and idea of what other researchers have done. Some steps to conduct the literature review are as follows: 1). Problem formulation; 2). Searching literature database; 3). Data evaluation; and 4). Analyzing. While the techniques in the literature review include: a). Comparing; b). Contrasting; c). Criticizing; d). Synthesizing, and e). Summarizing.

\section{Results}

In the result section, we divide our research findings related to problems formulation from the introduction. There are family health systems and family coping strategies in Indonesia.

\section{Indonesian Family Health System}

Mboi [23] stated in the research that Indonesia is a country with different populations with a series of demographic, epidemiological, social, economic, and political transitions. It is also experienced by healthcare system transitions. The healthcare system is essential to deliver health services that meet the entire population. The Ministry of Health $(\mathrm{MoH})$ and the Ministry of Home Affairs took on the primary responsibility for health services in Indonesia. The provincial and district governments that are under the Ministry of Home Affairs have the responsibility for planning and managing the healthcare services. While the Ministry of Health retains its responsibility for tertiary and specialist hospitals creates the regulation, provides resources, manages, and plans issues in public health, and ensures national health insurance to all of the citizens. This minister has issued Law Number 39 in 2016 related to the family health program. The program aims to facilitate families for health promotion services to form basic cure, rehabilitation, and attain the basic indicators of local services. Finally, this program will improve the realization of the basic services. The priority areas of the regulation are 1). Reducing the death of mothers and infants; 2). Decreasing the prevalence of stunting cases; 3). Implementing countermeasures against communicable disease, and 4). Reducing and managing non-communicable diseases. The implementation guidelines are focused on Community Health Center and contain some interventions: a). Regular home visiting; b). providing information packages for the family regarding the disease management; c). Communication platforms such as focused group discussion; d). Counseling, 
and e). various community meetings. While the serious shortcoming for the implementation are: 1 ). the lack of budget; 2). inadequate human resources; 3). the lack of support for local authorities; 4). the needs to improve the electronic facilities; 5). lack of community knowledge on the program; and 6). inconsistent coordination from the central authority [24].

The residents who have registered for BPJS (Health Insurance) can access all facilities including first-level and advanced health facilities. Health facilities in Indonesia are organized in a tier system. A non-emergency patient can access the primary care health facilities without a prior appointment, but when they need to access hospitals or more specific care, they will need to have a referral letter from the primary care facility. The healthcare facilities at the primary levels are delivered by the public sectors through the community health centers. Services from the private sector come from private clinics and practices of non-specialist healthcare providers (midwives, nurses). For emergencies, patients can get access to general hospitals in the emergency unit.

Since health is an important aspect of life among societies, WHO has issued dual health systems in the midst of the corona crisis. They were focusing on reducing coronavirus cases and promoting basic healthcare. The first mission to reduce the number of corona cases has failed and resulted in the economic sector. This crisis management to respond to the virus has shown that the country that has implemented health interventions extensively does not suffer from bad economic effects in the midterm. This means that pandemic has economic costs and outcomes. From Setiati' and Azwar' research [25], the government requires the instruments for successful implementation policy. They are mitigating actions and postrecovery on coronavirus crisis. The mitigation policy from their research covers the containment measures; the incentives for the workforce in health sectors, and supplying isolation facilities. Many actions are needed from society to contribute to facing the pandemic by prioritizing health in their everyday lifestyle.

The degrees of stress are related to age, education, sex, and status. Staying with many children in a country with a large number of COVID-19 cases is more stressful. This means the family needs public healthcare services both to handle mental and physical illness. In Indonesia, the government has announced the mandate to the citizens for doing the activities at home from working, studying, and praying. But these suggestions have not been fully implemented because the society need to adjust to the new ways. For almost family in Indonesia, staying at home with children while doing the works from home are stressful. This situation will lead to public mental health as the results from corona crisis. Furthermore, The Ministry of Health has announced a counseling hotline from call center 119 extension 8 to support physiology consultations. This program called SEJIWA which means SEHAT JIWA. Another supporting mental programs for society were released by The Indonesian Psychiatric Association that announced the guidelines and maintaining mental health procedures in corona crisis. It was according to WHO guidelines to include the time management for watching any particular media with COVID-19 news, performing relaxation and maintaining activities to reduce stress feeling, and sharing with the community. For supporting isolated person in Cipto Mangunkusumo Hospital, the local government of Jakarta Capital City creates POJOK SAHABAT as the means of communication among families' patients. This service helps the member of the family communicates by facilitating with the communications means. Currently, there is an online service for mental health support. From The mobile application in social media. This innovation established by some countries around Asia regions, South East Asia and Timor Leste [26]. 


\section{Indonesian Family Coping Strategies}

The price of basic needs in the midst of the COVID-19 crisis was high. The higher prices of food during pandemics include sugar, chilies, garlic, chicken, beef, and cooking oil. One cause is food distribution [27]. Many urban families in Indonesia reduce their consumption of rice. The consumption of instant noodles has increased slightly. The family tends to reduce animal-based protein, plant-based protein, fruits, and milk [28]. Family strategies to reduce food expenditure include prioritizing food for children, reducing the frequency of instant noodle consumption, reducing the number of cigarette consumption, and buying cheaper food. While the non-food expenditure strategies are: reducing the cost of dining out, reducing recreation cost, reducing the quality of clothes purchase, reducing the frequency of household furniture, and reducing savings. Besides expenditure strategy, there is family income strategy among Indonesian. These strategies are: applying savings, utilizing empty land to grow food crops, finding another jobs, owing money from relative, and converting items into cash to pawn loans. The Indonesian family characteristics that influence coping strategies are the location of residence, wife' and husband' education, also wife' and husband' income.

\section{Discussion}

We have concluded from many theories in literature reviews that family health is the conditions of all members that include many aspects from the social climate, the integrity, the function, the resistance to coping ability. The stressors influence every family among the functional or dysfunctional ones. These particular conditions related to the response of family in dealing with stressful situations are related to the characteristics of families, support and the degree of events. We also noted some aspect to the ability for overcoming the problematic situations are culture, social system, and norms where members of family have been raised. This sociocultural context plays the significant roles on healthcare, knowledge of certain disease, and the acts towards the difficult times. Therefore, the beliefs, behaviors and emotions are different among every individuals within the society. The mental health knowledge, treatments and education from psychological support, community, government, and health professionals are very essential in the midst of pandemic crisis.

Family coping knowledge that involves the cognitive and self-management skill to ensure mental health among every family member needs to be adjusted to the new ways and particular situations. The ways the strategies might be formed by communicating and acting positively to the external disturbance in the family and among societies. The strategies must be maintained to support community relationships and the family within social and family systems. These processes are very vital to deal with hard times and events. The social system and culture play significant role in the research results. The culture is based on the social system, religion, and support from the entire community. The different of sociocultural context and environment are shown from the level of economic of family, degree of education, age, sex, and status. These characteristics influence on the ways of a person' responds, adapts, and interacts with the crisis conditions that form collective and family coping. The roles of family professionals from government agencies and community support are critical to family adaptation and well-being. The literature review on the coping concept to a person or a collective action is influenced by individual or community characters. Emotional feelings such as self-blame and grumbling are correlated to health conditions that form the problem as anxiety and depression. The positive approach to particular emotions would be problem-solving which may contribute to reducing levels of stress. The social 
support from society and especially in the family are needed to form effective coping strategies to reduce particular problems. Since the coping strategy is an individual or group effort to reduce the problems, there are common pressure that needed a coping strategy is an economic pressure for example the burden of losing an income, change in the disadvantageous employment status, and economic difficulties. Job instability may makes pressure on the family. There are two types of coping strategies that families usually adopt including: reducing expenses and increasing income. The expenditure reducing strategies are easier to be carried out when there is any economic difficulties but an income-generating strategy needs special human resources and networks that cannot be done by all families in time of economic tension. Examples of expenditure reducing strategies include buying a cheaper type of food, reducing the frequency of food consuming, delaying treatment, and buying cheaper type of medicine, reducing the frequency of buying clothes and furniture. These actions are more carried out in the low-income family. Reducing the food consumption of animal based-protein while in the non-food dimension, many families do not change in spending education.

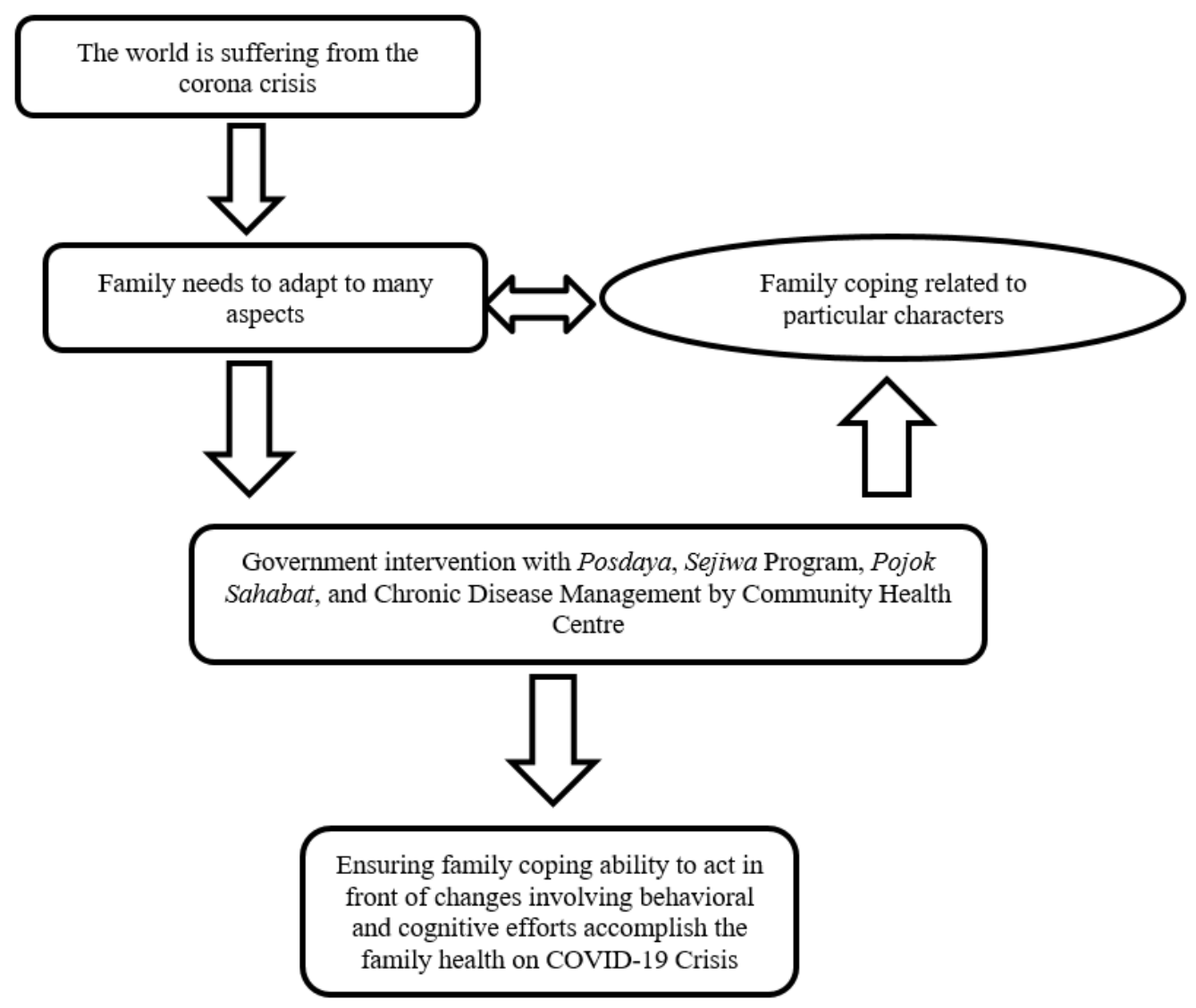

Figure 2. Indonesian Family Coping in the midst of Corona Crisis. Source: Authors, 2021.

The illustration above on the capacity of family coping strategies in Indonesia in the midst of the corona crisis is formed in a framework by the theory, findings, and results to answer the research question.

From figure 2, we analyze that these days the world is suffering from the corona crisis. Therefore, the family needs to adapt to many aspects. The family needs the coping ability as the support system in hard situations. These ways of dealing with the stressors are based on the family characters and sociocultural aspects where the family was raised. From the Indonesian context, community and government try to interfere the society with national 
health programs particularly with mental treatments support. Many of government actions were form in SEJIWA, POSDAYA, and POJOK SAHABAT to help the family in the community dealing with mental supports. Finally, these collective actions from government, health, and family professionals also communities around the regions would be used as strategies to ensure collective and family coping capacity in the midst of a pandemic crisis.

\section{Conclusion and Suggestion}

The conclusion of our documents analysis about family health is formed by many elements. The health elements are formed from characters and sociocultural context. The characters are referred to age, sex, status, level of economics, and degree of education. While the sociocultural contexts are derived from cultural background, ethnics, and religion. These diffusions of characters and sociocultural contexts would form individual, collective, and family coping in dealing with the stressors. Meanwhile, there are two types of coping strategies that families in Indonesia usually adopt including: reducing expenses and increasing income. Examples of expenditure reducing strategies include buying a cheaper type of food, reducing the frequency of food consumption, delaying treatment, and buying a cheaper type of medicine, reducing the frequency of buying clothes and furniture. Besides expenditure strategy, there is a family income strategy among Indonesian. These strategies are: applying savings, utilizing empty land to grow food crops, finding another jobs, owing money from relatives, and converting items into cash to pawn loans.

Apart from the explanation, The Indonesian Government should be synergized with many levels of government agencies including The Minister of Research and Technology Together with the Minister of Finance of Indonesia to improve and implement The Indonesia Endowment Fund for Education to increase research about COVID-19. The role of scientists is vital to fight against the virus together with the coping ability among Indonesian Families in the time of the COVID-19 pandemic.

\section{Acknowledgement}

We would like to acknowledge the Faculty of Social and Political Sciences Universitas Lampung, Indonesia as our affiliation institution for administrative and financial supports. This article has finished within great teamwork.

\section{References}

1. Subandi M. A., \& Good B. J. Shame as a cultural index of illness and recovery from psychotic illness in Java. In: Asian journal of psychiatry, 2018, 34, pp. 33-37. https://doi.org/10.1016/j.ajp.2018.04.005

2. Indrayana S., Guo S. E., Lin C. L., \& Fang S. Y. Illness perception as a predictor of foot care behavior among people with type 2 diabetes mellitus in Indonesia. In: Journal of Transcultural Nursing, 2019, 30(1), pp. 17-25. https://doi.org/10.1177\%2F1043659618772347

3. Fles R., Bos A. C. R. K., Rachmawati D., Waliyanti E., Tan I. B., Haryana S. M., \& Dewi F. S. T. The role of Indonesian patients' health behaviors in delaying the diagnosis of nasopharyngeal carcinoma. In: BMC public health, 2017, 17(1), pp. 510. https;//doi.org/10.1186/s12889-017-4429

4. Yulianti D., Meutia I. F., \& Sujadmiko B. Indonesia' Crisis Response to COVID-19 Pandemic: from Various Level of Government and Networks Actions to Policy. In: Journal of Public Administration, Finance and Law, 2020, 17(1), pp. 34-48.

5. Wahyuni N. C. Indonesia Currently Has Highest Covid-19 Mortality Rate in Asia. Jakarta Globe. 2020.

6. Weske U., Boselie P., Van Rensen E. L., \& Schneider M. M. Using regulatory enforcement theory to explain compliance with quality and patient safety regulations: the case of internal audits. In: BMC health services research, 2018, 18(1), pp. 1-6. 10.1186/s12913-018-2865-8

7. Huraerah A. Pengorganisasian dan pengembangan masyarakat: model dan strategi pembangunan berbasis kerakyatan. Humaniora. Universiti Sains Malaysia. 2011. 
8. Mardikanto T., \& Soebiato P. Pemberdayaan masyarakat dalam perspektif kebijakan publik. Alfabeta. Bandung. 2012.

9. Sulaiman A. I., Lubis D. P., Susanto D., \& Purnaningsih N. Komunikasi Stakeholder dalam Musyawarah Perencanaan Pembangunan (Musrenbang). In: Mimbar: Jurnal Sosial dan Pembangunan, 2015, 31(2), pp. 367378. https://doi.org/10.29313/mimbar.v31i2.1467

10. Amin M. KONSEP DAKWAH MELALUI PROGRAM POSDAYA BERBASIS MASJID (SUATU KAIIAN METODE DAKWAH BI AL-HĀL). In: Jurnal Dakwah Tabligh, 2012, 13(1), 97-108. https://doi.org/10.24252/jdt.v13i1.297

11. MUபONO, P. EVALUASI KINERJA POSDAYA SEBAGAI Program Pemberdayaan Masyarakat. In: Sosiohumaniora, 2016, 18(2), 115-121.

12. Dalimunthe H. H. B. Government Role of Urban Poor Community Empowerment Program in DKI Jakarta. In: Journal of Nonformal Education, 2017, 3(2), 97-109. https://doi.org/10.15294/jne.v3i2.10944

13. Buheji M. Coronavirus as a Global Complex Problem Looking for Resilient Solutions. In: Business Management and Strategy, 2020, 11(1), 94-109. https://doi.org/10.5296/bms.v11i1.16730

14. Baloshi M. B. Demographic Factor That Affect Employees Participation in Wellbeing Program in Bahrain. In: Int. J. Youth Eco, 2018, 2(2), 145-164. http://dx.doi.org/10.18576/ijye/020205

15. Astrup A., Dyerberg J., Elwood P., Hermansen K., Hu F. B., Jakobsen M. U., \& Nestel P. The role of reducing intakes of saturated fat in the prevention of cardiovascular disease: where does the evidence stand in 2010?. In: The American journal of clinical nutrition, 2011, 93(4), 684-688. https://doi.org/10.3945/ajcn.110.004622

16.Johar M., \& Maruyama S. Intergenerational cohabitation in modern Indonesia: filial support and dependence. In: Health Economics, 2011, 20(S1), 87-104. https://doi.org/10.1002/hec.1708

17. Snopkowski K., \& Sear R. Grandparental help in Indonesia is directed preferentially towards needier descendants: A potential confounder when exploring grandparental influences on child health. Social Science \& Medicine, 128, 105-114.Stone, L. (2016). Coping during a pandemic. In: disasters, 2015, 72(12), 1234-46. https://doi.org/10.1016/j.socscimed.2015.01.012

18. Mari E., Fraschetti A., Lausi G., Pizzo A., Baldi M., Paoli, E., \& Avallone F. Forced Cohabitation during Coronavirus Lockdown in Italy: A Study on Coping, Stress and Emotions among Different Family Patterns. In: Journal of Clinical Medicine, 2020, 9(12), 3906. https://doi.org/10.3390/jcm9123906

19. Flecha Ortiz J. A., Santos Corrada M. A., Lopez E., \& Dones V. Analysis of the use of memes as an exponent of collective coping during COVID-19 in Puerto Rico. In: Media International Australia, 2020, 178 (1), 168-181. https://doi.org/10.1177\%2F1329878X20966379

20. Iddi S., Obiri-Yeboah D., Aboh I. K., Quansah R., Owusu S. A., Enyan N. I. E., \& Armah F. A. Coping strategies adapted by Ghanaians during the COVID-19 crisis and lockdown: A population-based study. In: Plos one, 2021, 16(6). https://doi.org/10.1371/journal.pone.0253800

21. Khadilkar S. Coping with COVID Crisis. In:J Obstet Gynecol India, 2020, 70, 251-255 https://doi.org/10.1007/s13224-020-01358-w

22. Baniamin H. M., Rahman M., \& Hasan M. T. The COVID-19 pandemic: why are some countries coping more successfully than others?. In: Asia Pacific Journal of Public Administration, 2020, 42(3), 153-169. https://doi.org/10.1080/23276665.2020.1784769

23. Mboi N. Indonesia: on the way to universal health care. In: Health Systems \& Reform, 2015, 1(2), 91-97. https://doi.org/10.1080/23288604.2015.1020642

24. Afrianti F. Obstacles of the Implementation of the Healthy Indonesia Program with Family Approach (PISPK). In 2nd Sriwijaya International Conference of Public Health (SICPH 2019) 2020. (pp. 188-197). Atlantis Press. https://dx.doi.org/10.2991/ahsr.k.200612.026

25. Setiati S., \& Azwar M. K. Dilemma of prioritising health and the economy during COVID-19 pandemic in Indonesia. In: Acta Medica Indonesiana, 2020, 52(3), 196.

26. Kaligis F., Indraswari M. T., \& Ismail R. I. Stress during COVID-19 pandemic: mental health condition in Indonesia. In: Medical Journal of Indonesia, 2020. https://doi.org/10.13181/mji.bc.204640

27. KATADATA. (2020). Di tengah pandemic corona, harga pangan di Jakarta masih stabil tinggi.https://katadata.co.id/ekarina/berita/5e9a41f60273b/di-tengah-pandemi-corona-harga-pangan-dijakarta-masih-stabil-tinggi (10 Desember 2020).

28. Susilowati E. Family-coping strategies during the covid-19 pandemic in urban areas of Indonesia. Retrieved from http://www.ettysusilowati.id/wp-content/uploads/2020/10/Family-Coping-Strategies-During-TheCovid-19-Pandemic-Artikel-bu-etty_31Agustus2020.pdf 